East African Journal of Science, Technology and Innovation, Vol. 1 (1): 2019, 82-101.

This article is licensed under a Creative Commons license, Attribution 4.0 International (CC BY 4.0)

\title{
The biological integrity of streams and channels draining into the Rwizi River system in Western Uganda
}

${ }^{1 *}$ ATWEBEMBEIRE J., ${ }^{2}$ ANDAMA M., 1 BAZIRA J., 1LEJJU JB, 1TUMUSIIME J., ${ }^{1}$ WANGALWA R., ${ }^{1}$ YATUHA J

1Department of Biology, Faculty of Science, Mbarara University of Science and Technology

${ }^{2}$ Department of Biology, Muni University

*Corresponding author: jatwebembeirej@must.ac.ug

\begin{abstract}
Rwizi River, often called the life-line river, supports over five million people in Western Uganda and is a major contributor of freshwater to Lake Victoria. Surrounded by a large and rapidly growing population, the river has suffered anthropogenic disturbances whose impact on the integrity of the system is a subject of concern. Aquatic macroinvertebrates, used globally to monitor both short- and long-term environmental conditions, were thus used to assess the biological integrity of streams and channels draining into the river system. Macroinvertebrates were sampled for six months in 2017 encompassing the wet and dry seasons using the kick net sampling method. The macroinvertebrates were identified morphologically using peer reviewed identification keys and their pollution sensitivity scored using the Tanzanian River Scoring System (TARISS). The Shannon diversity index was computed per site and related to average score per taxon (ASPT). We collected a total of 5442 macroinvertebrates belonging to 54 families dominated by Chironomidae $(29.1 \%)$. Macroinvertebrate diversity increased with ASPT $(r=0.57 ; \mathrm{N}=131 ; \mathrm{P}=0.000)$. The water quality was generally poor and was not affected by the season $(\mathrm{t}=1.03 ; \mathrm{df}=64 ; \mathrm{P}=0.303)$ though sites had different water quality $(\mathrm{F}=$ 11.32; $\mathrm{df}=20 ; \mathrm{P}=0.000$ ) attributed the degree of anthropogenic disturbance. We concluded that river Rwizi system is highly degraded and thus recommend restoration of the entire catchment. Aquatic macroinvertebrates are good indicators of long-term conditions but less sensitive to short-term changes. Multiple approaches, biological and chemical, are encouraged during the restoration process.
\end{abstract}

Keywords: Bioassessment; ecosystem health; water quality; benthic macroinvertebrates; biomonitoring

Cite as: Jeninah Atwebembeire et el, 2019 The biological integrity of streams and channels draining into the Rwizi River system in Received: $\quad$ 19/06/19 Western Uganda East African Journal of Science, Technology and Innovation 1(1): 84-101.

Accepted: $\quad$ 15/10/19

Published: $\quad$ 25/10/19

\section{Introduction}

The task of preserving the integrity of freshwater reserves is today's greatest challenge for mankind (Hermoso, et al., 2016). This is majorly due to the anthropogenic related impacts on the quality of freshwater bodies. Access to safe water is a global priority (UNDP, 2015) and is a key point of discussion at several national and international platforms (Fagan, et al., 2015). Water and sanitation services contribute to sustainable development and cater for rapid economic development and social transformation. To ensure the desired water quality, states have invested in constant monitoring as a prerequisite for timely management interventions (Kaaya, Day, \& Dallas, 2015).

Rwizi river, a major contributor to the waters of L. Victoria, is an important freshwater reserve and supports a large and rapidly growing population in Western Uganda. It is the major source of water for people in South Western 
Uganda and their livestock (Atwebembeire et al., 2018,2019 ). It is also the main source of water for Uganda National Water and Sewerage Cooperation (NWSC) that supplies piped water to the urban centers in the region. Like other lotic ecosystems, Rwizi river provides not only water but also habitat to a range of ecologically and economically significant organisms such as vertebrates, insects, macrophytes, planktons and molluscs. In the recent past, Rwizi river has suffered increased anthropogenic disturbances whose impact on the quality of the water is a subject of inquiry in the region. Some information on the quality of Rwizi river is available (Atwebembeire et al., 2018, 2019; Egor \& Mbabazi, 2014; Ojok, et al., 2017). However, previous assessments were largely based on the water chemistry and in the main river only. This study used benthic macroinvertebrates, a biological assessment method, to establish the ecological integrity of the Rwizi river system including the streams and channels that pour into the river. The diversity and abundance of macroinvertebrate taxa was established and ecological health at particular sites (streams, channels and the main river) established based on the sensitivities of macroinvertebrate communities to disturbance.

Benthic macroinvertebrates inhabit the bottom substrate for most of their life time. Their ability to change water quality and low energy detritus into good quantities of food for higher organisms in the food web makes them significant in the aquatic food chain (Sharma, \& Vyas, 2013). They have been widely used for the assessment of the ecological status of water bodies (Dickens et al., 2018). Their limited mobility means that they can be used to evaluate localized environment stressors. Consequently, their distribution and abundance have been largely used as biomonitoring tool for fresh water pollution (Doberstein et al., 2000; Johnson et al., 1993; Musonge et al., 2019; Sreeja, 2018). Information on benthic river macroinvertebrate is very useful for evaluating not only the overall condition of the river but also its stream environments because these organisms are affected for a long period by different environmental stressors (Takashi et al., 2011). The sessile nature of macroinvertebrates reflects the condition of the water body they inhibit. However, different families have varying sensitivities towards different types of pollutants and provide vital information for water management (Muhazar et al., 2013).

\section{Materials and Methods}

\section{Study area}

The study was conducted on River Rwizi and its tributaries which are located in South Western Uganda (Fig 1). The river originates from Buhweju hills with various tributaries from the Nkore hills including Ntungamo and Sheema all comprising a catchment area of $2521 \mathrm{~km}^{2}$ (Mbarara District Local Government, 2013; Ojok et al., 2017). The river eventually pours its waters into Lake Victoria via the network of the Kooki lakes (Mburo, Kachera, Nakivale, and Kijanebarola) (Mukwaya \& Mugabe, 2012). Figure 1 shows the location of sampling sites in the upstream (Kasharara, Karungu, Kibimba and Nyakafumura) midstream (Nyakambu, Bugongi, Rugando, Nyaruteme and Karama) and downstream (Kafunjo, Kakyeka, Upper Kakyeka, Kitutu, Katete, Rwentondo, Rwentondo, Kiswahiri Nyamabare). Sampling sites were purposively selected according to the land use activities, source of pollution that is, point and non-point sources. The upstream and midstream sections of the river system were characterized by intensive agriculture and livestock production while the downstream area was characterized by urbanization, industrialization and farming activities.

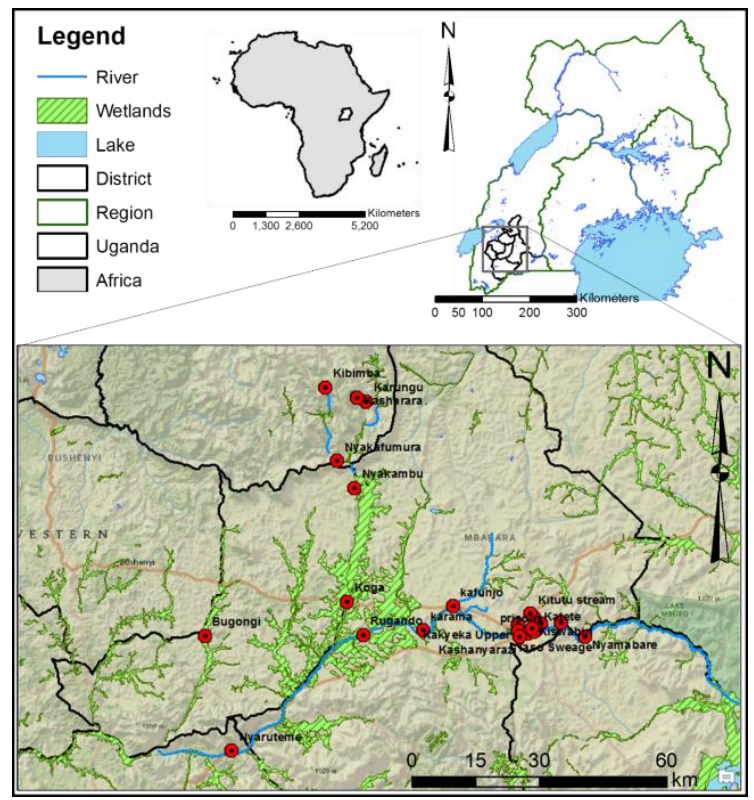

Figure 1 Map of Uganda showing the location river Rwizi system and the sampled sites

\section{Climate}


The South western region of Uganda experiences a wet and a dry season, with a bimodal precipitation pattern. The long rains occur in March to May and the short rains in November and December. The dry seasons occur from December to February and June to August (Bashemereirwe, 2009). The River Rwizi basin receives a mean annual rainfall of about $987 \mathrm{~mm}$.

\section{Research Design}

The research design was both qualitative and quantitative with the former involving identification of all the microbenthic taxa, human activities and vegetation type. Quantitative data of the abundance of taxa was collected and used to compute diversity indices.

\section{Sampling Strategy}

Sampling was done once a week for six months in March to May during the wet season and June to August in the dry season. Purposive sampling was done from different river zones including the upstream and midstream with intensive agriculture and the downstream urbanization areas. Each zone was sampled twelve times between March to May and June to August though the samples were not collected from necessarily from the same points. Each site was sampled for 60 minutes by one person and the latitude, longitude and altitude recorded using a Garmin GPS (Garmin GPSMAP 64). Human impact at each sampling site and the surrounding habitat was recorded according to the nature of disturbance which was classified according to the following criteria; no disturbance, agricultural and industrial waste water, sand mining, livestock watering point, irrigation zone, road construction, urbanization, natural forest, wetland, pasture/grassland, agriculture zone, tree plantation and so on. The sampling protocols was duly reviewed and approved by the Research Ethical Committee (REC) of Mbarara University of Science and Technology.

\section{Macroinvertebrate Sampling}

Macroinvertebrates sampling was done using a modified sampling protocol adopted from the Tanzanian River Scoring System (TARISS) approach (Kaaya et al., 2015). A scoop net with diameter of $30 \mathrm{~cm}$ and $1 \mathrm{~mm}$ mesh attached to a long metal handle was placed on the stream bed against the flow and the substrate in front of the net agitated by simple kicks steps. Samples were collected from different biotopes including stones, vegetation and gravel sand mud, leaf pack, tree roots etc. A total of twenty jabs in each of the various types of habitats were made where one dip net "jab" involved forcing the dip net against the stream bottom repeatedly, starting close to sampler's body and finishing with arms fully outstretched. However, sampling technique differed depending on habitat conditions as explained below.

Vegetation on the edge of river banks and aquatic vegetation (submerged vegetation in the river channel e.g. filamentous algae, roots and stems of floating vegetation) were considered during sampling. Approximately two meters length at any particular site was sampled. The net was vigorously pushed back and forth along the marginal vegetation while moving upstream in order to catch dislodged organisms. When sampling aquatic vegetation, the net was placed below the overhanging vegetation and moved in a bottom-up motion, jabbing at the bank several times to loosen organisms with the whole process taking five minutes. For the leaf packs, the pack was shaken to release organisms in water, and then quickly scooped up with the net in order to capture both the organisms and the leaves. In the case of tree roots, snags (accumulations of debris) and submerged logs, an area of approximately $3 \times 3 \mathrm{ft}$ in size was used in which the net was positioned downstream to ensure that dislodged material floats into it.

Sampling of stones included stones in the river current and stones out of current. While sampling stones in current, the net was placed close to and downstream of the kicked stones to allow dislodged organisms to be carried into the net by the water current. For the stones out of current, the stones were turned over to dislodge organisms. In bedrock-dominated areas, hands and feet were used to rub off the attached organisms, while the disturbed area was continuously swept by the scope net for approximately five minutes.

Sampling in gravel, sand and mud was conducted for a about one-minute stirring and shuffling one's feet and continuously sweeping the net to catch dislodged organisms. In stream sections with slow water flow, the net was jabbed into the bottom in a sweeping motion. In sections with a faster flow, the sampler stood upstream of the net and held it against the stream bottom and then kicked it so that the flow could wash the organisms into the net. The 
scooping of sand and mud into the net was avoided by sweeping it sufficiently far from the feet and allowing few seconds for large sediment particles to settle down.

The macroinvertebrates from the different biotopes at each site were pooled together in a container and preserved using $80 \%$ ethanol and then transported to the Biology laboratory at Mbarara University of Science and Technology for further processing.

The macroinvertebrate samples were sorted and identified to the required taxonomic level according to the Tanzania River Scoring System (Kaaya et al., 2015) using keys from East and South Africa (Day \& de Moor, 2002; Day et al., 2001a, 2001b; Day, Harrison, \& de Moor, 2002; Stewart, \& Louw, 1999; de Moor et al., 2003; Stals \& de Moor, 2007; Zwick, 2004). Clitellata were identified to sub class level, while families Baetidae and Hydropsychidae were identified to species level and all other macroinvertebrates to family level. The identified taxa were assigned sensitivity scores and the average score per taxon (ASPT) at each site computed according to Dickens \& Graham, (2002 and Kaaya et al. (2015). Water quality index at a site as indicated by ASPT values was computed from total sum of sensitivities of taxa (Kaaya et al., 2015) divided by the total number of taxa at that site. Taxa with sensitivities of $0-5$ were considered as having high pollution tolerance, 6-10 as having moderate tolerance and $11-15$ as having low pollution tolerance (Gerber \& Gabriel, 2002). The proportions of the different macroinvertebrate taxa present in River Rwizi was obtained by summing up the total number of each taxon during entire study period and the relative abundance was computed.

\section{Data analysis}

The macroinvertebrate taxa abundance data was entered in MS Excel ver. 2013 and used to compute the relative abundancies of the different taxa. Shannon's diversity index of was computed using PAST computer software (Natural History Museum, Oslo) and site differences in diversity were tested using oneway ANOVA from SPSS statistical software (SPSS Inc, Chicago, IL, USA). Taxa diversity was correlated with water quality (inferred from ASPT values) across sampling sites using Pearson's correlation coefficient to examine the relationship between water quality and ecological complexity. Seasonal variation in macroinvertebrate diversity and water quality was analysed using paired samples students' $\mathrm{t}$ test. All analysis was done at 5\% level of significance.

\section{Results}

A total of 5442 macroinvertebrates belonging to 54 TARISS taxa (53 families and 1 sub class) were collected from the river system (Table 1). The most abundant families were Chironomidae $(29.71 \%)$ and Baetidae (11.67\%) while the least abundant families were Corydalidae, Pschomayiidae, Chlorocyphidae and Platycnemididae all with a relative abundance of $0.02 \%$ each.

Table 1 The abundancies and relative abundance of orders and families/classes and sub classes of macroinvertebrates sampled from River Rwizi system in the period March to August 2017. Taxonomic level of classification was as required by the Tanzanian River Scoring System. 


\begin{tabular}{|c|c|c|c|}
\hline Order/class & Family/sub class & Abundance & Relative abundance (\%) \\
\hline Amphipoda & Corydalidae & 1 & 0.02 \\
\hline \multirow[t]{7}{*}{ Coleoptera } & Dytiscidae & 186 & 3.42 \\
\hline & Elmidae & 11 & 0.20 \\
\hline & Gyrinidae & 143 & 2.63 \\
\hline & Helodidae/scritidae & 2 & 0.04 \\
\hline & Hydraenidae & 7 & 0.13 \\
\hline & Hydrophilidae & 66 & 1.21 \\
\hline & Psephenidae & 3 & 0.06 \\
\hline \multirow[t]{9}{*}{ Diptera } & Ceratopogonidae & 13 & 0.24 \\
\hline & Chironomidae & 1617 & 29.71 \\
\hline & Culicidae & 185 & 3.40 \\
\hline & Dixidae & 5 & 0.09 \\
\hline & Ephydridae & 9 & 0.17 \\
\hline & Psychodidae & 76 & 1.40 \\
\hline & Simuliidae & 4 & 0.07 \\
\hline & Syrphidae & 196 & 3.60 \\
\hline & Tipulidae & 26 & 0.48 \\
\hline \multirow[t]{8}{*}{ Ephemeroptera } & Baetidae & 635 & 11.67 \\
\hline & Caenidae & 48 & 0.88 \\
\hline & Heptageniidae & 86 & 1.58 \\
\hline & Leptophlebiidae & 24 & 0.44 \\
\hline & Oligoneuridae & 14 & 0.26 \\
\hline & Parecnomina & 4 & 0.07 \\
\hline & Teloganodidae & 67 & 1.23 \\
\hline & Tricorythidae & 32 & 0.59 \\
\hline \multirow[t]{8}{*}{ Hemiptera } & Belostomatidae & 36 & 0.66 \\
\hline & Corixidae & 84 & 1.54 \\
\hline & Gerridae & 23 & 0.42 \\
\hline & Naucoridae & 58 & 1.07 \\
\hline & Nepidae & 4 & 0.07 \\
\hline & Notonectidae & 16 & 0.29 \\
\hline & Pleidae & 10 & 0.18 \\
\hline & Veliidae & 35 & 0.64 \\
\hline Clitellata & Hirudinae (sub class) & 3 & 0.06 \\
\hline \multirow[t]{5}{*}{ Mollusca } & Thiaridae & 377 & 6.93 \\
\hline & Corbiculiidae & 2 & 0.04 \\
\hline & Lymnaeidae & 40 & 0.74 \\
\hline & Physidae & 84 & 1.54 \\
\hline & Planorbidae & 143 & 2.63 \\
\hline
\end{tabular}

There was low diversity of macroinvertebrates across sites ranging from $\mathrm{H}^{`}=2.17$ at
Kashanyarazi to $\mathrm{H}^{`}=0.11$ at Nyakambu (Fig 2) compared to the maximum expected $\left(\mathrm{H}^{`}=4.5\right)$. The Shannon index values showed significant differences in macroinvertebrate diversity 
across sites $(\mathrm{P}=0.000 ; \mathrm{F}=4.573 ; \mathrm{df}=21)$ when subjected to One-Way ANOVA test. However, seasonal variation in diversity at sites was insignificant $(\mathrm{P}=0.558)$ with the wet season having relatively higher diversity than the dry season as shown in Fig 3.

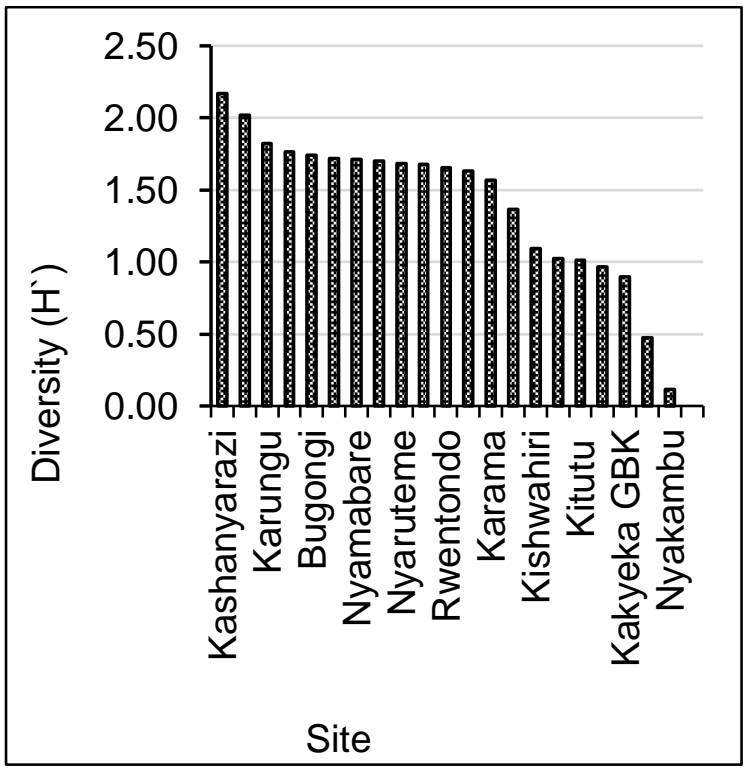

Figure 2 Shannon's diversity of macroinvertebrates sampled from different sites in the River Rwizi system from March to August 2017. All invertebrates collect from a site for the entire study period were pooled together to compute the diversity.

ASPT values correlated moderately and positively with diversity $(\mathrm{r}=0.57 ; \mathrm{N}=131 ; \mathrm{P}=$ 0.000 ) indicating that sites with good water quality tend to have a higher macroinvertebrate diversity (Fig 3). Hence Kashanyarazi with the highest diversity (Fig 2) recorded the best water quality than the other sites.

Figure 3 Scatter plot of Pearson's correlation of Shannon index of macroinvertebrate diversity and TARISS Average Score Per Taxon (ASPT) in River Rwizi system

Seasonal variation in water quality was not significant though higher values of ASPT were recorded in the wet season $(4.29 \pm 1.58)$ than the dry season $(4.09 \pm 1.81 ; \mathrm{t}=1.03 ; \mathrm{df}=64 ; \mathrm{P}=0.303$; Fig 6). This also concurs with the seasonal variation in the diversity of macroinvertebrates

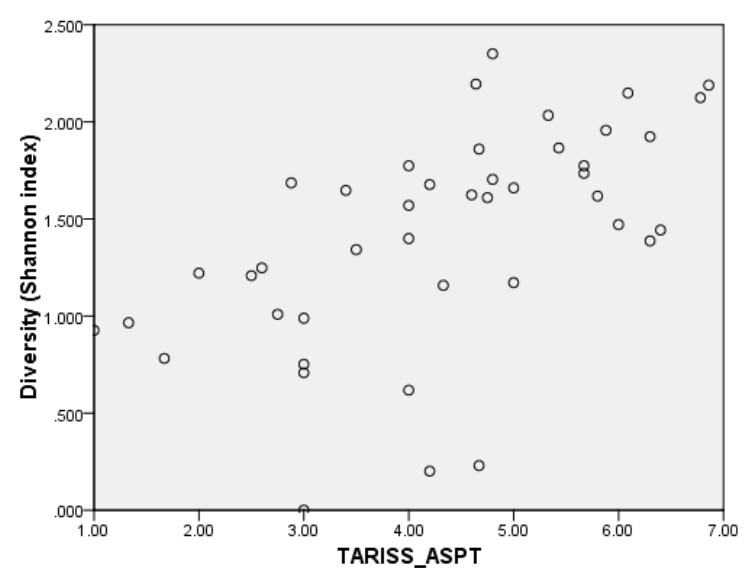

in the study sites where a slightly higher diversity was recorded in the wet season (Fig 4).

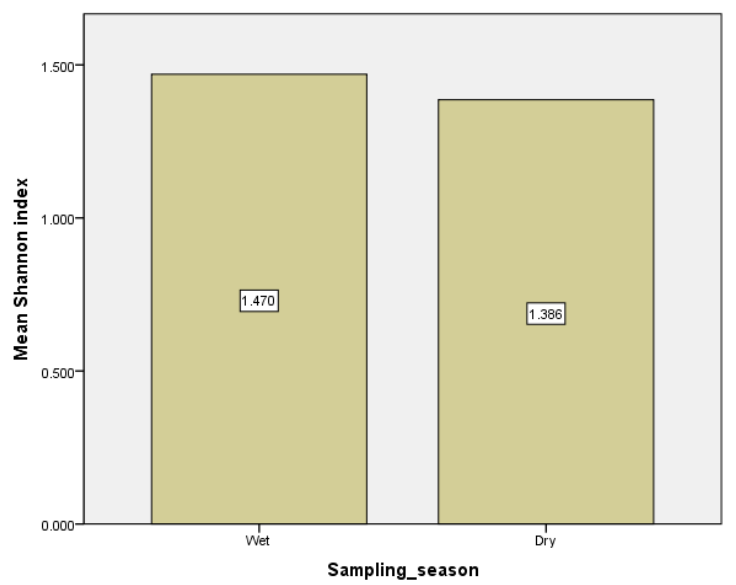

Figure 3 Seasonal variation in Shannon index of diversity of macroinvertebrates sampled from different sites in the River Rwizi system from in the dry and wet seasons.

However, sites have different water quality index $(\mathrm{F}=11.32 ; \mathrm{df}=20 ; \mathrm{P}=0.000)$ with the highest water quality index recorded at Kashanyarazi and the lowest at Bus park with ASPT values of 7.3 and 1.3 respectively. The Rwizi system was generally polluted/disturbed with only Kashanyarazi having "moderate water quality" while other sites lie in the "poor water quality" to "very poor water quality" (Fig 5). The cumulative effects of interacting disturbance factors contribute to pollution at a site (Dusabe et al., 2019). Hydro morphological and limnological characteristics of river Rwizi are greatly affected by the human activities hence threatening the existence of sensitive macroinvertebrates. 


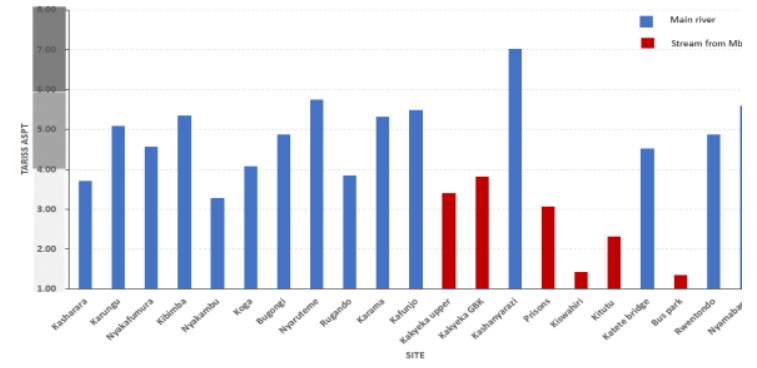

Figure 4 Variation in Average Score per Taxon (ASPT) at different sites upstream to downstream of River Rwizi using the Tanzanian River Scoring system (TARISS). Water quality classification follows Aquilina (2013), whereby light shading indicates 'very poor' quality, moderate shading 'poor' quality, and dark shading 'moderate' water quality

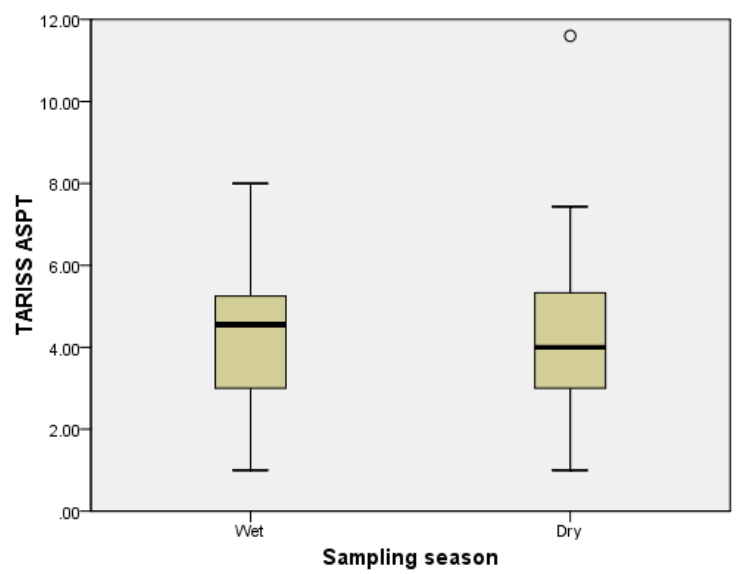

Figure 5 Seasonal variation of water quality in river Rwizi indicated by TARISS ASPT

\section{Discussion}

The Rwizi river system sampled for six months in the wet and dry seasons had a somewhat rich but simple community of macroinvertebrate comprising of 54 families highly dominated by chironomids constituting $29.71 \%$ of the 5442 individuals collected and 11 rare families with abundance $\leq 5$ (Table 1). The Chironomid dominance could be due to the very high colonization potential (Rádková et al., 2014) and adaptability to a variety of habitats given their high diversity. Many Chironomid larvae are also known to be highly tolerant to polluted aquatic environments (Rádková et al., 2014) and thus their sensitivity scores to poor water quality are often low in various bioassessment systems (Dickens \& Graham, 2002; Hawkes, 1998; Kaaya et al., 2015). Population pressure and unsustainable agricultural practices greatly degrade the Rwizi catchment to an extent that in many sites, the riparian vegetation is cleared and cultivated to the banks. Consequently, a lot of organic matter and inorganic nutrients (Atwebembeire et al., 2018) are eroded into the river creating conditions that are suitable for the tolerant groups of organisms like Chironomids (and other dipterans) at the same time reducing the survival of sensitive taxa.

The diversity of macroinvertebrates in the Rwizi system was generally low $\left(\mathrm{H}^{`}=1.42 \pm 0.56\right.$; Fig 2$)$ across sites. $\mathrm{H}^{\prime}$ was used to represent community structures in River Rwizi since rare and abundant species are expected to be equally important (Morris et al., 2014) in the computation of the water quality equivalent ASPT using TARISS (bioassessment system based on presence of taxa with no regard to abundance). The Shannon's diversity index increased as water quality (represented by ASPT) increased across the sites (Fig 3) suggesting that less polluted aquatic habitats support a more complex community of organisms compared to few dominant tolerant organisms in polluted water. Studies have shown that diversity and ecological functioning of stream communities are strongly controlled by variation in the hydrological processes (Biggs et al., 2005; Rawi et al., 2014). Some species are very sensitive to alteration in ecohydrological conditions given their substantial requirements for feeding, reproduction and growth while others are tolerant to temporary and/or persistent changes of hydrological, thermal, physical or chemical conditions (Rawi et al., 2014). Our findings thus emphasize that the highly disturbed/polluted sites on River Rwizi due to practices like urbanization, poor waste treatment and disposal, and encroachment on the river buffer zones (Atwebembeire et al., 2018, 2019) offer limited chances for survival of highly diverse microbenthic communities of sensitive taxa but support few water pollution tolerant species. However, site differences in microbenthic diversity $(\mathrm{p}=0.000 ; \mathrm{F}=4.573 ; \mathrm{df}=$ 21) are due to the differences in site characteristics given the fact that benthic macroinvertebrates communities adapt to longterm prevailing conditions at a site, the very basis of bioassessment of ecological integrity.

River Rwizi system is greatly disturbed with generally poor to very poor water quality save for few isolated cases with moderate water quality (e.g. Kashanyarazi; Fig 5). The drainage streams/channels from Mbarara Municipality were found to have the poorest water quality. 
However, despite being in the Mbarara Municipality, Kashanyarazi site had the best water quality in the entire system.

The Rwizi catchment is characterised by a number of small-holder famers who practice unsustainable farming methods. Studies have shown that $55 \%$ of the small holder farmers in the Rwizi catchment do not practice soil and water conservation et al., 2013) which could subsequently lead to a lot of soil erosion into the river. Site differences in water quality exist $(\mathrm{F}=$ 11.32; $\mathrm{df}=20 ; \mathrm{P}=0.000$. The very poor water quality (ASPT 1-4; Aquilina, 2013; Dusabe et al., 2019) was found at sites with very high levels of anthropogenic impact. Kasharara site (believed by local residents to be the source of river of River Rwizi), for example, was cultivated. The small volume of water for a river in its early stages (i.e. at Kasharara site) is very susceptible to pollution by agricultural inputs which could result in survival of only tolerant taxa of macroinvertebrates. At Nyakambu site, brick laying, heavy papyrus harvesting, deforestation, mud fishing and a lot of garbage damping into the river and a bridge were observed. At Rugando site, a lot of sand mining was taking place along the river course combined with cattle drinking directly from the river, human and livestock waste dumping, agricultural waste and vegetation litter all leading to negative impact in and around the banks of River Rwizi.

Urbanisation contributes the greatest damage to the water quality of river Rwizi. Inlets from the municipality had very poor water quality (Fig 5 ) due to damping of untreated domestic solid and liquid waste industrial effluent, runoffs from washing bays, garages, agricultural fields with tree nursery beds and crop farming sometimes taking place up to the river bank as was similar to (Atwebembeire et al., 2019; Dusabe et al., 2019). These activities increase nutrient loading and sedimentation creating conditions intolerable to many pollution sensitive taxa. Contrary to the trend, however, Kashanyarazi is a site in an urban setting but with moderate water quality higher than any other site in the Rwizi system. This site is located on the greatly meandering section of the river with reduced flow velocity and colonized by dense mats of the water hyacinth (Eichhornia crassipes). The water weed is reported to proliferate in highly eutrophic waterbodies (Balirwa et al., 2009) which supports the findings that River Rwizi is enriched with nutrients (Atwebembeire et al., 2018). The water hyacinth is known for phytoremediation by removing large quantities of dissolved nutrients like nitrogen from the water (Priya \& Selvan, 2017; Wang \& Yan, 2017) while at the same time reducing dissolved oxygen concentration for lentic waterbodies. Since river Rwizi is a lotic system with water hyacinth at the edges of the stream. The result is that sites like Kashanyarazi have higher water quality despite being close to areas with high levels of degradation. This thus confirms the argument that bioassessment protocols based on aquatic macroinvertebrates depict conditions prevailing in a relatively short stretch of the river as was similar to (Dusabe et al., 2019) where conditions are somewhat similar and is less affected by conditions upstream.

In Africa, bioassessment indices based on aquatic macroinvertebrates such as the Tanzania Rivers Scoring System (TARISS) in Tanzania (Kaaya et al., 2015) and the South African Scoring System (SASS) in South Africa (Dickens $\&$ Graham, 2002) have been developed. These systems are based on the presence or absence of taxa without considering abundance which makes them less sensitive to seasonal changes, especially when the season affects abundance. As a result, the River Rwizi system showed no seasonal changes in water quality. Macroinvertebrate communities take a time lag in responding to changes in water quality (Leps et al., 2016) and this is the basis for their use in evaluation of sustained ecological conditions at a site. Thus, rapid bioassessment systems are very reliable cost-effective methods for studying ecological integrity at a site for a relatively long period of time.

Despite the great ecological and economic value of River Rwizi, the poor water quality associated to anthropogenic disturbance could be attributed to poor enforcement of existing laws as the main cause for the deterioration of lotic ecosystems

Mukwaya and Mugabe (2012) noted that "There is a lack of effective policy framework and implementation mechanisms in place at district level. There is also the lack of effective implementation of existing legislation and regulatory mechanisms".

\section{Conclusion}


The water quality status of River Rwizi and its streams was assessed using macro-invertebrate as indicator organism with the help of Tanzania River Scoring System. River Rwizi and its streams were having poor water quality, with many downstream streams and channels as the most polluted, followed by midstream and upstream channels. Mbarara municipality contributes the greatest damage to water quality of river Rwizi majorly through untreated/poorly treated municipal effluent draining through the streams and channels to the main river.

Our findings indicate that river Rwizi system has poor to very poor water quality. We therefore suggest to refrain human activities especially farming away from riparian zone to buffer zone in order to restore the river. The community need to be continuously educated about the value of the river for the greater good of the communities and the country as a whole and the impending danger of the complete 'death' of the river with the rapidly growing population and associated pressure to the river resource. We therefore advocate for swamp restoration, proper waste disposal and protection of the catchment area. Continuous monitoring using multiple ecosystem health assessment approaches (physicochemical \& biomonitoring methods) would give a complete picture of the Rwizi catchment area with time and thus inform local governments on the next steps. More research could be done to quantify the extent of damage caused by various human activities and the degree to which they harm the ecological and economic value of river Rwizi.

\section{Acknowledgements}

The authors would like to thank African Development Bank Hest, Mbarara University of Science and Technology, for providing the financial support. Biology Department, Faculty of Science, where samples were analyzed in their laboratory. We also thank Agaba Edson and Araka Nickson the research assistants and Babirye Aisha Laboratory assistant for all the for assistance whenever called upon, friends and all well-wishers.

\section{Data Availability Statement}

The datasets generated and analysed during the current study are available https://issues.pangaea.de/browse/PDI-20492.

\section{Conflict of interests}

The authors have no conflict of interest to declare.

\section{Ethic approval}

This study was approved by Uganda National Council for Science and Technology (UNCST) and Mbarara University Research Ethical Committee (REC).

\section{References}

Aquilina, R. (2013). Pre-restoration assessment of the Hogsmill and River Wandle.

Bournemouth, UK.

Atwebembeire, J., Andama, M., Yatuha, J., Lejju, J. B., Rugunda, G. K., \& Bazira, J. (2019). The Physico-Chemical Quality of Effluents of Selected Sewage Treatment Plants Draining into River Rwizi , Mbarara Municipality , Uganda. Journal of Water Resource and Protection, 11(3), 20-36. https://doi.org/10.4236/jwarp.2019.1110 02

Atwebembeire, J., Bazira, J., Kagoro, G., Yatuha, J., Andama, M., \& Bunny, J. L. (2018). The Physico-Chemical Quality of Streams and Channels Draining into River Rwizi, South Western Uganda. Journal of Water Resource and Protection, 10(09), 817845. https://doi.org/10.4236/jwarp.2018.1090 47

Balirwa, J., Wanda, F., \& Muyodi, F. (2009). Impacts of Water Hyacinth and Water Quality Change on Beneficial Uses of Lake Victoria, Uganda. In 13th World Lake Conference (pp. 1-5). Wahum, China.

Bashemereirwe, C. (2009). Socio-economic Activities Impacting on Rwizi Riverine Wetlands, South Western Uganda, 2009.

Biggs, B. J. F., Nikora, V. I., \& Snelder, T. O. N. H. (2005). linking scales of flow variability to lotic ecosystem structure and function, 298(July 2004), 283-298. https://doi.org/10.1002/rra.847

Day, J., \& de Moor, I. J. (2002). Guides to the Freshwater Invertebrates of Southern AfricaVolume 5: Non-Arthropods. Water Research Comission (Vol. 5). Pretoria, South Africa. https://doi.org/10.2989/AJAS.2009.34.2. 14.901

Day, J., de Moor, I., Stewart, B., \& Louw, A. (2001a). Guides to the Freshwater Invertebrates of South Africa. Volume 3: Crustacea II. Water Research Comission (Vol. 3). Pretoria, South Africa.

Day, J., de Moor, I., Stewart, B., \& Louw, A. (2001b). Guides to the Freshwater 
Invertebrates of Southern Africa. Volume 4: Crustacea III. Water Research Comission (Vol. 4). Pretoria.

Day, J., Harrison, A., \& de Moor, I. (2002). Guides to the Freshwater Invertebrates of Southern Africa. Volume 9: Diptera (Vol. 9). Gezina, South Africa.

Day, J., Stewart, B., IJ, de M., \& Louw, A. (1999). Guides to the Freshwater Invertebrates of South Africa. Crustacea I. Water Research Comission. Pretoria, South Africa.

de Moor, I., \& Day, J. (2002). Guides to the Freshwater Invertebrates of Southern Africa. Volume 6: Arachnida \& Mollusca. Water Research (Vol. 6). Gezina, South Africa.

de Moor, I. J., Day, J. a, \& de Moor, F. C. (2003). Guides to the Freshwater Invertebrates of South Africa Volume 7: Insecta I. Water Research Comission. Gezina, South Africa.

Dickens, C., Cox, A., Johnston, R., Davison, S., Henderson, D., Meynell, P. J., \& Shinde, V. (2018). Monitoring the Health of the Greater Mekong 's Rivers. Vientiane, Lao: CGIAR Research Program on Water, Land and Ecosystems (WLE).

Dickens, C. W., \& Graham, P. (2002a). The South African Scoring System ( SASS ) Version 5 Rapid Bioassessment Method for Rivers. African Journal of Aquatic Science, 27(1), 1-10. https://doi.org/10.2989/16085914.2002.9 626569

Dickens, C. W., \& Graham, P. M. (2002b). The South African Scoring System (SASS) Version 5 Rapid Bioassessment Method for Rivers. African Journal of Aquatic Science, 27(1), 1-10. https://doi.org/10.2989/16085914.2002.9 626569

Doberstein, C. P., Karr, J. R., \& Conquest, L. L. (2000). The effect of fixed-count subsampling on macroinvertebrate biomonitoring in small streams. Freshwater Biology, 44(2), 355-371. https://doi.org/10.1046/j.13652427.2000.00575.x

Dusabe, M., Wronski, T., Gomes-silva, G., Plath, M., Albrecht, C., \& Apio, A. (2019). Biological water quality assessment in the degraded Mutara rangelands , northeastern Rwanda. Environmental Monitoring and Assessmen, 191(139), 1-13. https://doi.org/10.1007/s10661-0197226-5

Fagan, G. H., Linnane, S., McGuigan, K. G., \&
Rugumayo, A. I. (2015). Water Is Life. Practical Action Publishing Ltd. https://doi.org/10.3362/9781780448893

Gerber, A., \& Gabriel, M. (2002). Aquatic invertebrates of South African rivers field guide.

Hawkes, H. A. (1998). technical note origin and development of the biological monitoring working party score system. Water Research, 32(3), 964-968. https://doi.org/10.1016/s00431354(97)00275-3

Hermoso, V., Abell, R., Linke, S., \& Boon, P. (2016). The role of protected areas for freshwater biodiversity conservation: challenges and opportunities in a rapidly changing world. Aquatic Conservation: Marine and Freshwater Ecosystems, 26(April), 3-11. https://doi.org/10.1002/aqc.2681

Johnson, R. K., Wiederholm, T., \& Rosenberg, D. M. (1993). Freshwater biomonitoring using individual organisms, populations, and species assemblages of benthic macroinvertebrates. Chapman and Hall, New York(Usa)., 40-125. Retrieved from https://www.researchgate.net/profile/Ri chard_Johnson7/publication/292130029_ Freshwater_biomonitoring_using_individ uals_organisms_populations_and_species _assemblages_of_benthic_macroinvertebr ates/links/5771274308ae6219474a372b.pd $\mathrm{f}$

Kaaya, L. T., Day, J. A., \& Dallas, H. F. (2015). Tanzania River Scoring System ( TARISS ): a macroinvertebrate-based biotic index for rapid bioassessment of rivers. African Journal of Aquatic Science, 40(2), 109-117. https://doi.org/10.2989/16085914.2015.1 051941

Leps, M., Sundermann, A., Tonkin, J. D., Lorenz, A. W., \& Haase, P. (2016). Science of the Total Environment Time is no healer : increasing restoration age does not lead to improved benthic invertebrate communities in restored river reaches. Science of the Total Environment, The, 557558, 722-732.

https://doi.org/10.1016/j.scitotenv.2016. 03.120

Morris, E. K., Caruso, T., Fischer, M., Hancock, C., Obermaier, E., Prati, D., ... Nicole, W. (2014). Choosing and using diversity indices : insights for ecological applications from the German Biodiversity Exploratories, 3514-3524. 
https://doi.org/10.1002/ece3.1155

Moses Egor, Jolocam Mbabazi, M. N. (2014). International Journal of Chemistry and Materials heavy metal and nutrient loading of river rwizi by effluents from mbarara municipality, western uganda Jolocam Mbabazi Muhammad Ntale Contribution / Originality, 2(5), 36-47.

Mugonola, B., Deckers, J., Poesen, J., Isabirye, M., \& Mathijs, E. (2013). International Journal of Agricultural Sustainability Adoption of soil and water conservation technologies in the Rwizi catchment of south western Uganda. International Journal of Agricultural Sustainability, 11(3), 264-281.

https://doi.org/10.1080/14735903.2012.7 44906

Muhazar, A., Shuhaimi-Othman, M., Kutty, A. A., \& Desa, M. N. . (2013). No TitleMornitoring Urban River water using Macroinvertabrate and physico-chemical parameters. Biological Sciences, 6(ISSN 1727-3048/DOI:10.3923/jbs.2013.474.482).

Mukwaya, C., \& Mugabe, R. (2012). Cooperation in Management of Water Resources in the Ruizi Catchment, Southwestern Uganda. Directorate of Water Resources Management, Ministry of Water and Environment, Entebbe, Uganda.

Musonge, P. S. L., Boets, P., Lock, K., Damanik Ambarita, N. M., Forio, M. A. E., Verschuren, D., \& Goethals, P. L. M. (2019). Baseline assessment of benthic macroinvertebrate community structure and ecological water quality in Rwenzori rivers (Albertine rift valley, Uganda) using biotic-index tools. Limnologica, 75, 1-10. https://doi.org/10.1016/J.LIMNO.2018.1 2.001

Ojok, W., Wasswa, J., \& Ntambi, E. (2017). Assessment of Seasonal Variation in Water Quality in River Rwizi Using Multivariate Statistical Techniques, Mbarara Municipality, Uganda. Journal of Water Resource and Protection, 09(01), 8397. https://doi.org/10.4236/jwarp.2017.9100 7

Priya, E. S., \& Selvan, P. S. (2017). Water hyacinth (Eichhornia crassipes ) - An efficient and economic adsorbent for textile effluent treatment - A review. Arabian Journal of Chemistry, 10, S3548S3558. https://doi.org/10.1016/j.arabjc.2014.03.0 02

Rádková, V., Syrovátka, V., Bojková, J., Schenková, J., Křoupalová, V., \& Horsák, M. (2014). The importance of species replacement and richness in small-scale diversity patterns of aquatic macroinvertebrates in spring fens. Limnologica. https://doi.org/10.1016/j.limno.2014.03.0 01

Rawi, C. S., Al-shami, S. A., Madrus, M. R., \& Ahmad, A. H. (2014). Biological and ecological diversity of aquatic macroinvertebrates in response to hydrological and physicochemical parameters in tropical forest streams of Gunung Tebu, Malaysia : implications for ecohydrological assessment. Ecohydrology, 7(February 2013), 496-507. https://doi.org/10.1002/eco.1368

Semalulu, O., \& Kaizzi, C, K. (2012). Overview of the status of soil resource in Uganda, and the needs and priorities for its sustainable management, 14.

Sharma, R., Kumar, A., \& Vyas, V. (2013). Diversity of Macrozoobenthos in Morand River- A Tributary of Ganjal River in Narmada Basin, 1(1), 57-65.

Sreeja, J. (2018). Biomonitoring of Paravur Lake in Kerala Using Macro-Invertebrates. In Environmental Pollution (pp. 477-485). Springer, Singapore. https://doi.org/10.1007/978-981-10-57922_38

Stals, R., \& de Moor, I. (2007). Guides to Freshwater Invertebrates of Southern Africa. Volume 10: Coleoptera (Vol. 10). Pretoria, South Africa: Water Research Comission.

Takashi, K., Dongbin, W., Akira, K., Natsumi, Y., Takashi, K., \& Kohei, U. (2011). Evaluation of Relationship Between Biological Safety and Benthic Macroinvertebrate Assemblages in the. Water and Environment Technology, 9(4), 381-389.

UNDP. (2015). Sustainable Development Goals (pp. 1-24).

Wang, Z., \& Yan, S. H. (2017). Impact of Water Hyacinth on Aquatic Environment in Phytoremediation of Eutrophic Lakes. In Water Hyacinth: Environmental Challenges, Management and Utilization (pp. 204-249). China.

Zwick, P. (2004). A key to the West Palearctic general of stoneflies (Plecoptera) in the 
larval stage. Forschungsinstitut

Scenkenberg/Forchungsstation Für Mittelgebirge, 1-38.

https://doi.org/10.1016/S0075-

9511(04)80004-5. [dataset]

https://issues.pangaea.de/browse/PDI20492 
